GLOBAL JOURNAL OF SOCIAL SCIENCES VOL 15, 2016: 1-11

COPYRIGHT@ BACHUDO SCIENCE CO. LTD PRINTED IN NIGERIA. ISSN 1596-6216

www.globaljournalseries.com; Info@globaljournalseries.com

\title{
UNDERGRADUATES' VIEW OF LECTURERS' AGE AS A FACTOR IN THEIR TEACHING EFFECTIVENESS
}

\author{
B. A. BASSEY \\ (Received18 March 2016; Revision Accepted 15 April 2016)
}

\begin{abstract}
This study presents students' view on whether lecturers' age is a factor in their teaching effectiveness. In this study, 3800 undergraduates were selected to evaluate the teaching effectiveness of 380 lecturers in University of Calabar- Nigeria. A 42-item six-point Likert scaled student evaluation of academic staff teaching effectiveness questionnaire by the researcher elicited responses on the teaching effectiveness of the lecturers. The data collected were collated and analysed using One-way ANOVA and Fisher's (LSD) multiple comparison analyses. Each of the eight sub-variables of the hypothesis was tested at .05 alpha levels. The results showed a significant influence of lecturers' age on: Knowledge of subject matter, classroom management skill, ability to motivate students, assessment of students learning activities, relationship with students, assessment of students learning activities, relationship with students, and overall teaching effectiveness. The age of lecturers, therefore, is a function of their teaching effectiveness. The study recommends that workshops, seminars, conference should be organized to enlighten lecturers of all ages on the invaluable importance of student evaluations of instruction/instructor in Nigerian educational system.
\end{abstract}

KEYWORD:Assessment; Evaluation; Lecturers' age; Teaching effectiveness.

\section{INTRODUCTION}

The issue of student evaluation of teaching, effectiveness is always an interesting topic to many, hence the gamut of literature on it, particularly in foreign lands. But literature on lecturers' age as a function of their teaching effectiveness, particularly in tertiary institutions in Nigeria is not robust, hence this study. Findings of this study will enrich literature in the area.

Majority of literature on typical concerns of students' evaluation of teaching effectiveness show those students judgements about their teachers then to be pretty stable. All basically demonstrate that student evaluations can be used to improve instruction, and that student's feedback is therefore most important for correction, and forms part of the growth and development of the teachers.

Teaching is effective to the extent that the teacher acts in ways that are favourable in developing skills, understanding, work habits and desirable attitudes in the students. The attributes favourable for such actions are "sympathetic attitude towards his students, a thorough knowledge of his subject matter, confidence in his own ability to teach, a co-operative spirit with co-workers and a constant interest in expanding his knowledge and that of his students" (Ndinechi, 2000:14).

Specifically, literature has identified professional attributes or characteristics that constitute effective teaching to include: knowledge of subject matter; classroom communication skill; effective teaching methods/strategies; classroom management skill; ability to motivate students; assessment of student learning activities; and relationship with students. For an instructor to be effective, he/she must possess high level of all of the attributes listed above. The level of teaching effectiveness, therefore, is the sum of the levels of all these

B.A. Bassey,Research, Measurement and Evaluation Unit, Department of Educational Foundations,

University of Calabar,Calabar, Nigeria. 
characteristics. "The biological crystal ball is very cloudy when we come to aging", says one researcher. "No one fully understands it" states another researcher. Even so, gerontologists (scientists who study aging) have attempted to define it. Simply put, they say aging is the chronological time that someone has existed. Aging is the toll that the passing years take on an individual (Awake, 1999:4).

Obvious answer to the question "is mental decline a normal part of aging"? remains a challenge. Forgetfulness occurs at all ages, and changes in mental function that an older person may experience are not usually from dementia. While some memory loss is common in later life, "most elderly people live out their lives in complete control of their mental abilities," writes Dr. Michael T. Levy, chairman of behavioural science at Staten Island University Hospital in New York. True, younger people usually surpass older ones in the speed at which they recall specific facts. But, "if you take away the timer", says neurologist Richard Restak, "older people generally perform at least as well as their younger counterparts". In fact, with appropriate education and training, healthy older brains continue to learn, to remember, and even to improve specific abilities (Awake, 2006:4-5).

Research results on the influence of age on teaching effectiveness are mixed, much of which is strong on polemics and weak on evidence. On whether instructor performance declines with age, Sheehan, Dobson and Smith (2008) reveal that age variables lose significance in all models except that for the physical and biological sciences. This loss in significance, they reason is not surprising given that the influence of age on teaching effectiveness at later ages was shown to be of very small size. Although teaching effectiveness appears to improve with age, the teachers rated as most effectives seem to retire early so that the remaining pool of professors will be of lower average effectiveness rating.

College teachers' ages and personalities, and students' course grades, gender, enrolment status, academic abilities, and ages were investigated as predictors of student evaluations of academic staff. An evaluation form containing 7 items reflecting the personality trait of extraversion and 8 items reflecting teaching effectiveness was used to collect data form 351 undergraduates. Teachers extraversion (.79) and teachers' ages (-.8) were correlated highest, students' gender was correlated lowest (.08) with teaching effectiveness. Hierarchical regressions revealed that teachers' extraversion was the only significant predictor of student evaluation (beta .76, $\mathrm{p}<.001$ ) after controlling for enrolment status, course grades and students' ages (Radmacher\& Martin, 2011).

An instructor's ratings for a given course tend to be relatively consistent over successive years. There is not much variation in student ratings for an individual instructor regardless of whether the form is administered to current students or alumni. Also, it was revealed that there is little or no relationship between the following characteristics of students and their ratings of instruction; age, grade point average, year in college, and academic ability (Marsh \& Dunkin, 2002).

Researchers studied older people to measure such qualities as "insight, sound judgement, perspective and ability to weigh conflicting values and generate good problemsolving strategies". According to US News World Report, the study showed that "older people consistently outshine younger people on all measures of wisdom, offering more thoughtful, sophisticated advice". Studies also show that "although it often takes older people longer than youngsters to make a decision, it is usually a better one" (Awake 1999:11).

According to Dr. Richard L. Sprott, of the National Institute of Aging quoted from Awake (1999:4), aging is the slow deterioration of those portions of our systems that allow us to respond adequately to stresses". Most experts agree, though, that coming up with a clear definition of aging remains a challenge. Molecular biologist Dr. John Medina explains why: "From head to toe, from protein to DNA, from birth to death, untold battalions of processes unfold to create the aging of a 60-trillion-celled human". Small wonder that many researchers concluded that aging is "the most complex of all biological problems" (Awake, 1999:11).

Whether or not lecturers' age is a function of their teaching effectiveness, as evaluated by their students, is the concern of this study. The results of this study will also reveal the level of the lecturers' effectiveness in each of the professional characteristics under study.

\section{Purpose of the study}

The purpose of this study was to determine the influence of lecturers' age on their teaching effectiveness, with respect to:

a. Knowledge of Subject Matter (KSM); 

b. Classroom
Communication
skills
(COMSK);
c. Effectiveness methods/strategies (ETM)
teaching
d. Classroom Management Skills (CLMSK)
e. Ability to Motivate Students (ABMS)
f. Evaluation of Students Learning Activities (EVSLA)
g. Relationship with Students (RWS)
h. Overall Teaching Effectiveness (OVTE)

\section{Hypothesis of the study}

The teaching effectiveness of lecturers is not significantly influenced by the age of the lecturers, with respect to:

i. Knowledge of Subject Matter (KSM);

ii. Classroom Communication skills (COMSK);

iii. Effectiveness methods/strategies (ETM) teaching

iv. Classroom Management Skills (CLMSK)

v. Ability to Motivate Students (ABMS)

vi. Evaluation of Students Learning Activities (EVSLA)

vii. Relationship with Students (RWS)

viii. Overall Teaching Effectiveness (OVTE)

\section{Method}

The research design adopted for this study was ex post facto. The research area was the University of Calabar, Nigeria. The population of the study comprised all 646 lecturers and about 10,000 undergraduates of all the 10 faculties in the University. The sampling techniques employed were stratified random sampling and simple random sampling. 3800 undergraduate students, 1900 males and 1900 females, were used to evaluate 380 lecturers' teaching effectiveness, 10 students-five males and five females - for each lecturers. The instruments used for data collection were a 7-item academic staff questionnaire (ASQ) measuring lecturers' personal/demographic variables, and a 42 -item university students' evaluation of teaching effectiveness questionnaire (USETEQ) for evaluation of teaching effectiveness.

USETEQ had six parts, each with six questionnaire items on one of the seven identified professional characteristics of teaching, namely; knowledge of subject matter; classroom communication skill; effective teaching methods/strategies; classroom management skill; ability to motivate student, relationship with students, and assessment of students learning activities. All the 42 items of USETEQ were of Likert type on a six-point scale. The USETEQ was trial-tested using split half reliability method. The derived $r$-values which ranged from .83 to 91 were considered high enough to justify the use of the instrument for the study.

All the copies of the questionnaire (ASQ) for the academic staff and 3800 copies of the questionnaire (USETEQ) for the students were administered personally by the researcher with the help of some research assistants. All the copies of the questionnaires given out were retrieved. The data collected were collated and analyzed using one-way ANOVA and Fisher's (LSD) multiple comparison analyses. Each of the eight sub-variables of the hypothesis was tested at .05 alpha level.

\section{RESULTS}

The teaching effectiveness of lecturers in University of Calabar, as evaluated by their students, is not significantly influenced by the age of the lecturers.

The independent variable in this hypothesis is age of the lecturers, while the dependent variable is lecturers' teaching effectiveness. The respondents in the sample were categorized into four groups based on the categories as indicated for age of the lecturers, namely; Group 1 (20-30yrs); Group 2 (31-40yrs); Group 3 (41-50yrs); Group 4 (51years and above).

The statistical technique used to test this hypothesis was one-way ANOVA. The hypothesis was tested on each of the eight subvariables on the depended variable. The results of the data analysis are presented in Tables 1, 2 and 3 . The group means and standard deviations for the four groups on each of the eight subvariables of the dependent variable are presented in Table 1. The actual results of ANOVA are presented in Table 2, while Fisher's LSD multiple comparison analysis are presented in Table 3.

From the above results in Table 2, the calculated F-values of the eight sub-variables of the dependent variable are each higher than the critical F-ratio of 2.61 at .05 alpha level with 3 and 376 degrees of freedom. The null hypothesis was, therefore, rejected for each of these subvariables. This means that there is a significant influence of lecturers' age on their teaching 
effectiveness, with regards to all these subvariables of the teaching effectiveness.

Given the significant F-value, a detailed multiple comparison analysis using Fisher's Least Square Difference (LSD) was done to determine exactly which group (20-30yrs; 31-40yrs; 41-50 yrs; 51 yrs and above) differed significantly from each other in terms of the lecturers' teaching effectiveness in University of Calabar. The results of these analyses were presented in Table 3.

The pattern of the influence of academic staff age on their teaching effectiveness is as follows:

\section{Knowledge of subject matter (KSM)}

The significant Fisher's t-value of $-2.82,3.47$ and -6.35 indicate that lecturers' teaching effectiveness with respect to knowledge of subject matter for the lecturers aged $31-40$ years $($ mean $=25.30), 41-50$ years $($ mean $=25.61)$ and
51 years and above (mean $=26.97$ ) are significantly higher than lecturers' teaching effectiveness with respect to knowledge of the subject matter for lecturers aged 20-30 years (mean $=24.13)$. Also, the significant Fisher's tvalue of -4.66 and -3.66 indicate that lecturers' teaching effectiveness with respect to knowledge of subject matter for the lecturers' aged 41-50 years (mean $=25.61$ ) and 51 year and above (mean $=26.97$ ) are significantly higher than lecturers' teaching effectiveness with respect to knowledge of subject matter for lecturers' aged $31-40$ years (mean $=25.30)$. The non-significant Fisher's t-value of -0.94 indicates that lecturers' teaching effectiveness with respect to knowledge of subject matter for lecturers aged $41-50$ years (mean $=25.61$ ) is not significantly different from lecturers' teaching effectiveness with respect to knowledge of subject matter for lecturers aged 31-40 years (mean = 25.30). 
TABLE 1: Group means and standard deviation of academic staff teaching effectiveness based on their age

\begin{tabular}{|c|c|c|c|c|c|}
\hline$\overline{\text { Sub variable }}$ & & Group & $\mathrm{N}$ & Mean & SD \\
\hline \multirow[t]{4}{*}{ KSM } & 1 & (20-30yrs) & 54 & 24.13 & 2.94 \\
\hline & 2 & (31-40yrs) & 132 & 25.30 & 3.01 \\
\hline & 3 & (41-50yrs) & 110 & 25.61 & 2.33 \\
\hline & 4 & $\begin{array}{l}\text { (51-yrs and above) } \\
\text { Total }\end{array}$ & $\begin{array}{l}84 \\
380\end{array}$ & $\begin{array}{l}26.94 \\
25.59\end{array}$ & $\begin{array}{l}1.72 \\
2.70\end{array}$ \\
\hline \multirow[t]{5}{*}{ COMSK } & 1 & (20-30yrs) & 54 & 22.61 & 1.98 \\
\hline & 2 & (31-40yrs) & 132 & 23.61 & 1.76 \\
\hline & 3 & (41-50yrs) & 110 & 24.56 & 2.11 \\
\hline & 4 & (51-yrs and above) & 84 & 25.60 & 2.09 \\
\hline & & Total & 380 & 24.20 & 2.20 \\
\hline \multirow[t]{5}{*}{ ETM } & 1 & (20-30yrs) & 54 & 22.69 & 1.92 \\
\hline & 2 & (31-40yrs) & 132 & 23.62 & 1.88 \\
\hline & 3 & (41-50yrs) & 110 & 24.55 & 2.02 \\
\hline & 4 & (51-yrs and above) & 84 & 26.05 & 1.84 \\
\hline & & Total & 380 & 24.29 & 2.21 \\
\hline \multirow[t]{4}{*}{ CLMSK } & 1 & (20-30yrs) & 54 & 20.56 & 1.79 \\
\hline & 2 & (31-40yrs) & 132 & 21.41 & 3.01 \\
\hline & 3 & (41-50yrs) & 110 & 21.55 & 1.82 \\
\hline & 4 & $\begin{array}{l}\text { (51-yrs and above) } \\
\text { Total }\end{array}$ & $\begin{array}{l}84 \\
380\end{array}$ & $\begin{array}{l}23.11 \\
21.71\end{array}$ & $\begin{array}{l}1.98 \\
2.46\end{array}$ \\
\hline \multirow[t]{5}{*}{ ABMS } & 1 & (20-30yrs) & 54 & 22.37 & 1.40 \\
\hline & 2 & (31-40yrs) & 132 & 23.49 & 1.66 \\
\hline & 3 & (41-50yrs) & 110 & 24.10 & 1.94 \\
\hline & 4 & (51-yrs and above) & 84 & 25.35 & 2.19 \\
\hline & & Total & 380 & 23.92 & 2.05 \\
\hline \multirow[t]{5}{*}{ EVSLA } & & (20-30yrs) & 54 & 22.27 & 1.71 \\
\hline & & (31-40yrs) & 132 & 23.14 & 1.66 \\
\hline & & (41-50yrs) & 110 & 23.97 & 1.94 \\
\hline & & (51-yrs and above) & 84 & 25.50 & 1.93 \\
\hline & & Total & 380 & 23.78 & 2.09 \\
\hline \multirow[t]{5}{*}{ RWS } & 1 & (20-30yrs) & 54 & 21.57 & 2.52 \\
\hline & 2 & (31-40yrs) & 132 & 22.45 & 2.10 \\
\hline & 3 & (41-50yrs) & 110 & 22.88 & 2.07 \\
\hline & 4 & (51-yrs and above) & 84 & 24.66 & 2.09 \\
\hline & & Total & 380 & 22.93 & 2.37 \\
\hline \multirow[t]{5}{*}{ OVTE } & 1 & (20-30yrs) & 54 & 155.47 & 10.05 \\
\hline & 2 & (31-40yrs) & 132 & 162.26 & 9.1567 \\
\hline & 3 & (41-50yrs) & 110 & 167.18 & 10.23 \\
\hline & 4 & (51-yrs and above) & 84 & 177.38 & 10.19 \\
\hline & & Total & 380 & 166.06 & 12.07 \\
\hline
\end{tabular}


TABLE 2: Results of the analysis of variance (ANOVA) of the influence of age on lecturers' teaching

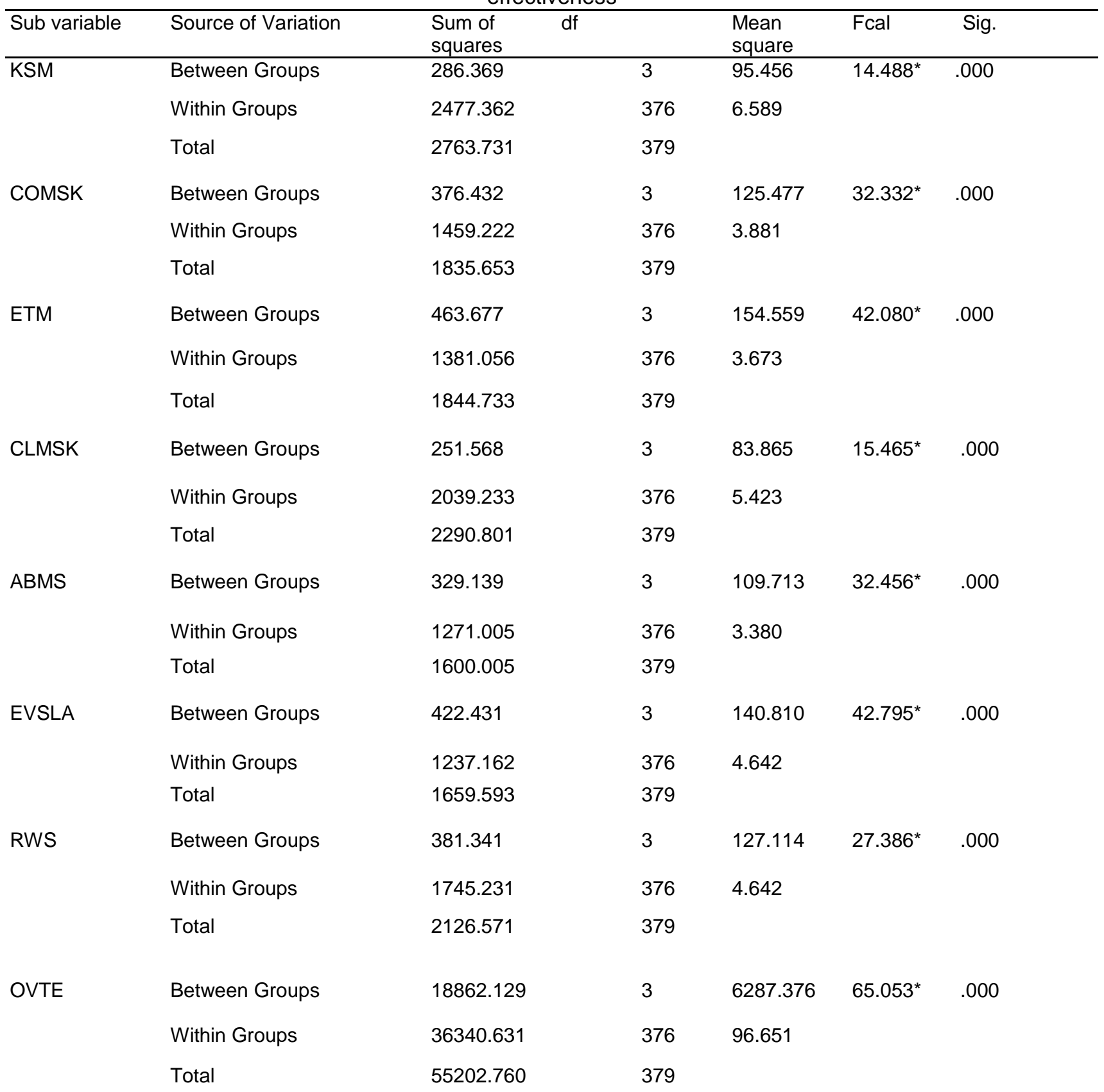

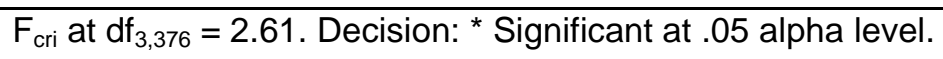


TABLE 3: Results of Fisher's LSD multiple comparison analysis of influence of age on academic staff teaching

\begin{tabular}{|c|c|c|c|c|c|}
\hline $\begin{array}{l}\text { Sub-categories of } \\
\text { teaching effectiveness }\end{array}$ & Age & $\begin{array}{l}20-30 \mathrm{yrs} \\
(\mathrm{N}=54)\end{array}$ & $\begin{array}{l}31-40 y r s \\
(N=132)\end{array}$ & $\begin{array}{l}41-50 y r s \\
(N=110)\end{array}$ & $\begin{array}{l}\text { 51yrs \& above } \\
(N=84)\end{array}$ \\
\hline \multirow[t]{4}{*}{ KSM } & $20-30 y r s$ & $24.13^{\mathrm{a}}$ & $-1.17^{b}$ & -1.48 & -2.84 \\
\hline & $31-40 y r s$ & $-2.82^{\mathrm{c} *}$ & 25.30 & -0.31 & -1.67 \\
\hline & $41-50 y r s$ & $-2.82^{*}$ & -0.94 & 25.61 & -1.36 \\
\hline & $\geq 51-y r s$ & $\begin{array}{l}-3.47^{*} \\
-6.35\end{array}$ & $\begin{array}{l}-4.66^{*} \\
\text { MSW }=6589\end{array}$ & $-366^{*}$ & 26.97 \\
\hline \multirow[t]{4}{*}{ COMSK } & $20-30 y r s$ & $22.61^{\mathrm{a}}$ & $-1.00^{b}$ & -1.95 & -3.05 \\
\hline & $31-40 y r s$ & $-3.14 c^{*}$ & 23.61 & -0.95 & -2.05 \\
\hline & $41-50 y r s$ & $-5.96^{*}$ & -3.73 & 24.56 & -1.10 \\
\hline & $\geq 51$-yrs & $-8.88^{*}$ & $\begin{array}{l}-7.45^{\star} \\
\text { MSW }=\mathbf{3 . 8 8 1}\end{array}$ & $-3.85^{\star}$ & 25.66 \\
\hline \multirow[t]{4}{*}{ ETM } & $20-30 y r s$ & $22.69^{\mathrm{a}}$ & $-0.93^{\mathrm{b}}$ & -1.86 & -3.36 \\
\hline & $31-40 y r s$ & $-3.00 c^{*}$ & 23.62 & -0.93 & -2.43 \\
\hline & $41-50 y r s$ & $-5.84^{*}$ & $-3.75^{\star}$ & 24.55 & -1.50 \\
\hline & $\geq 51$-yrs & $-10.06^{*}$ & $\begin{array}{l}-9.08^{*} \\
M S W=3.673\end{array}$ & $-5.40^{*}$ & 26.05 \\
\hline \multirow[t]{4}{*}{ CLMSK } & $20-30 y r s$ & $20.56^{a}$ & $-0.85 b$ & -0.99 & -2.55 \\
\hline & $31-40 \mathrm{yrs}$ & $-226^{\mathrm{c} *}$ & 21.41 & -0.14 & -1.70 \\
\hline & $41-50 y r s$ & $-2.56^{*}$ & -47 & 21.55 & -1.56 \\
\hline & $\geq 51-y r s$ & $-6.28^{*}$ & $\begin{array}{l}-5.23^{*} \\
M S W=5.423\end{array}$ & $-462 s^{*}$ & 23.11 \\
\hline \multirow[t]{4}{*}{ ABMS } & $20-30 y r s$ & $23.37^{\mathrm{a}}$ & $-1.12 b$ & -1.73 & -2.98 \\
\hline & $31-40 y r s$ & $3.78^{\mathrm{c} *}$ & 23.49 & -0.61 & -1.86 \\
\hline & $41-50 y r s$ & $-5.66^{*}$ & $-2.57^{*}$ & 24.10 & -1.25 \\
\hline & $\geq 51$-yrs & $-9.30^{*}$ & $-7.25^{\star}$ & $-4.69^{*}$ & 25.35 \\
\hline \multirow[t]{4}{*}{ EVSLA } & $20-30 y r s$ & $22.27^{\mathrm{a}}$ & $\begin{array}{l}M S W=3.380 \\
-0.90^{\mathrm{b}}\end{array}$ & -1.70 & -3.23 \\
\hline & $31-40 y r s$ & $-3.07^{c *}$ & 23.17 & -0.80 & -2.33 \\
\hline & $41-50 y r s$ & $-5.64^{\star}$ & $-3.41^{*}$ & 23.97 & -1.53 \\
\hline & $\geq 51$-yrs & $-10.21^{*}$ & $-9.20^{*}$ & $-5.82^{*}$ & 25.50 \\
\hline \multirow[t]{3}{*}{ RWS } & $20-30 y r s$ & $21.57^{\mathrm{a}}$ & $\begin{array}{l}M S W=3.290 \\
-0.88^{\mathrm{b}}\end{array}$ & -1.31 & -3.09 \\
\hline & $\begin{array}{l}31-40 \mathrm{yrs} \\
41-50 \mathrm{yrs}\end{array}$ & $\begin{array}{l}-2.53^{\mathrm{c}} \\
-3.66^{*}\end{array}$ & $\begin{array}{l}22.45 \\
-1.54\end{array}$ & $\begin{array}{l}0.43 \\
22.88\end{array}$ & $\begin{array}{l}-2.21 \\
-1.78\end{array}$ \\
\hline & $\geq 51-y r s$ & $-8.23^{\star}$ & $\begin{array}{l}-7.35^{*} \\
M S W=4.642\end{array}$ & $-5.70^{*}$ & 24.66 \\
\hline \multirow[t]{4}{*}{ OVTE } & $20-30 y r s$ & $155.47^{*}$ & $-67.79^{\mathrm{b}}$ & 11.71 & -21.91 \\
\hline & $31-40 y r s$ & $-428^{\mathrm{c} *}$ & 162.26 & -4.92 & -15.12 \\
\hline & 41-50yrs & $-7.17^{\star}$ & $-3.87^{*}$ & 167.18 & -10.20 \\
\hline & $\geq 51-y r s$ & -12.78 & $\begin{array}{l}-11.01^{*} \\
\text { MSW=96.651 }\end{array}$ & $-5.03^{*}$ & 177.38 \\
\hline
\end{tabular}

* Significant at .05 alpha level ( $\left.\mathrm{t}_{\mathrm{cri}}=1.97\right)$

a - Group means placed along the major diagonals

$\mathrm{b}$ - Differences between group means are above the major diagonals

c -Fisher's t-values are below the major diagonals

Communication skills (COMSK) 
The significant Fisher's t-values of $-31.14,-5.96$ and -8.88 indicate that lecturers' teaching effectiveness with respect to classroom communication skills lecturers' aged 31-40 yrs $($ mean $=23.6), 41-50$ years $($ mean $=24.56)$ and 51 yrs and above (mean $=25.66$ ) are significantly higher than lecturers' teaching effectiveness with respect to communication skills for the lecturers aged 20-30 years (mean $=22.61$ ). Also, the significant Fisher's t-values of -3.73 and -7.45 indicate that lecturers' teaching effectiveness with respect to communication skills for lecturers aged 41-50 years (mean $=24.56)$ and 51 years and above (mean $=25.66$ ) are significantly higher than lecturers' teaching effectiveness with respect to communication skills for lecturers aged 41-50 years (mean $=24.56$ ) and 51 years and above (mean $=25.66$ ) are significantly higher than lecturers' teaching effectiveness with respect to communication skills for lecturers aged 31-40 years (mean $=23.61$ ). the significant Fisher's t-value of -3.85 indicates that lecturers' teaching effectiveness with respect to communication skills for lecturers aged 51 years and above (mean $=25.66$ ) is significantly higher than teaching effectiveness with respect to communication skills for lecturers aged 41-50 years $($ mean $=24.56$ ).

\section{Effective teaching methods/strategies (ETM)}

The significant Fisher's t-values of $3.00,-5.84$, and -10.06 indicate that lecturers' teaching effectiveness with respect to effective teaching methods or strategies for lecturers aged 31-40 years $($ mean $=23.62), 41-50$ year $($ mean $=24.55)$ and 51 years and above (mean $=26.05$ ) are significantly higher than lecturers' teaching effectiveness with respect to effective teaching methods or strategies for lecturers aged 20-30 years (mean $=22.69$ ). The Fisher's t-values of 3.75 and -9.08 indicate that lecturers' teaching effectiveness with respect to effective teaching methods/strategies for lecturers aged 41-50 years (mean $=24.55$ ) and 51 years and above (mean $=26.05$ ) are significantly higher than lecturers' teaching effectiveness with respect to effective teaching methods/strategies for lecturers aged $31-40$ years (mean $=23.62$ ). Also, the significant Fisher's t-value of -5.40 indicates that lecturers' teaching effectiveness with respect to effective teaching methods/strategies for lecturers aged 51 years and above (mean = 26.05) is significantly higher than the teaching effectiveness with respect to effective teaching method/strategies for lecturers aged 41-50 years (mean $=24.55)$.

\section{Classroom management skills (CLMSK)}

The significant Fisher's t-values of $-2.26,-2.56$ and -6.28 indicate that lecturers' teaching effectiveness with respect to classroom management skills for lecturers aged $31-40$ years $($ mean $=21.41), 41-50$ years $($ mean $=21.55)$ and 51 years and above (mean $=23.11$ ) are significantly higher than lecturers' teaching effectiveness with respect to classroom management skills for lecturers aged 20-30 years (mean $=20.56)$. Also, the significant Fisher's tvalues of -5.23 and -4.62 indicate that lecturers' teaching effectiveness with respect to classroom management skills for lecturers aged 41-50 years $($ mean $=21.55)$ and 51 years and above (mean = 23.11) are significantly higher than lecturers' teaching effectiveness with respect to classroom management skills for lecturers aged $31-40$ years (mean $=21.41)$. The non-significant Fisher's tvalue of -0.47 indicates that lecturers' teaching effectiveness with respect to classroom management skills for lecturers aged 41-50 years (mean $=21.55$ ) is not significantly different from lecturers' teaching effectiveness with respect to classroom management skills for lecturers aged $31-40$ years $($ mean $=21.41)$.

\section{Ability to motivate students (ABMS)}

The significant Fisher's t-values of $-3.78,-5.66$, and -9.30 indicate that lecturers' teaching effectiveness with respect to ability to motivate students for lecturers aged 31-40 years (mean = $23.49), 41-50$ years (mean $=24.10$ ) and 51 years and above (mean $=25.35$ ) are significantly higher than lecturers' teaching effectiveness with respect to ability to motivate students for lecturers aged 20-30 years (mean $=22.37$ ). The significant Fisher's t-values of -2.57 and 7.25indicate that lecturers' teaching effectiveness with respect to ability to motivate students for lecturers aged $41-50$ years (mean $=24.10)$ and 51 years and above (mean $=25.35$ ) are significantly higher than lecturers' teaching aged $31-40$ years $($ mean $=23.49$ ). Also, the significant Fisher's t-value of -4.49 indicates that lecturers' teaching effectiveness with respect to ability to motivate students for lecturers aged 51 years and above (mean $=25.35$ ) is significantly higher than lecturers' teaching effectiveness with respect to ability to motivate students for lecturers aged 41 50 years $($ mean $=24.10)$. 


\section{Evaluation of students learning activities (EVSLA)}

The significant Fisher's t-values of $-3.07,-5.64$, and -10.21 indicate that lecturers' teaching effectiveness with respect to evaluation of students learning activities for lecturers aged 3140 years $($ mean $=23.17), 41-50$ years $($ mean $=$ 23.97) and 51 years and above (mean $=25.50$ ) are significantly higher than lecturers' teaching effectiveness with respect to evaluation of students learning activities for lecturers aged 2030 years (mean $=22.27$ ). The significant Fisher's t-values of -341 , and -920 indicate that lecturers teaching effectiveness with respect to evaluation of students learning activities for lecturers aged 41-50 years (mean $=23.97$ ) and 51 years and above (mean $=25-50$ ) are significantly higher than lecturers' teaching effectiveness with respect to evaluation of students learning activities for lecturers aged 41-50 years (mean = 23.97) Also, the significant Fisher's t-value of 582 indicates that lecturers' teaching effectiveness with respect to evaluation of students learning activities for lecturers aged 51 years and above (mean $=25.50$ ) is significantly higher than lecturers' teaching effectiveness with respect to evaluation of students learning activities for lectures aged 41-50 years (mean = 23.97.

\section{Relationship with students (RWS)}

The significant Fisher's t-values of $-253,-3.66$, and -8.23 indicate that lecturers' teaching effectiveness with respect to relationship with students for learning activities for lecturers aged $31-40$ years $($ mean $=24.45), 41-50$ years $($ mean $=22.88)$ and 51 years and above (mean $=24.66$ ) are significantly higher than lecturers' teaching effectiveness with respect to relationship with students for lecturers aged 20-30 years (mean = $21.57)$. Also, the significant Fisher's t-values of 7.35 , and -5.70 indicate that lecturers teaching effectiveness with respect to relationship with students for lecturers aged 41-50 years (mean = 22.88 ) and 51 years and above (mean = 26-66) are significantly higher than lecturers' teaching effectiveness with respect to relationship with of students for lecturers aged 31-40 years (mean = 22.45). The non-significant Fisher's t-value of 145 indicates that lecturers' teaching effectiveness with respect to relationship with students for lecturers aged 41-50 years (mean = 22.88 ) is not significantly different from lecturers' teaching effectiveness with respect to relationship with students for lecturers aged 3140 years $($ mean $=22.45)$.

\section{Overall teaching effectiveness (OVTE)}

This implies that interactive effects of the various sub-categories or components of teaching effectiveness. The significant Fisher's t-values of -24.28, 73.17, and 12.78 indicate that lecturers' teaching effectiveness with respect to the interactive effects of the various sub-categories (OVTE) for lecturers aged 31-40 years (mean = 162.26), 41-50 years $($ mean $=167.18)$ and 51 years and above (mean $=177.38$ ) are significantly higher than lecturers' teaching effectiveness with respect to overall teaching effectiveness for lecturers aged 20-30 years (mean $=155.77)$. The significant Fisher's t-values of -3.87 , and -11.01 staff aged $41-50$ years (mean $=167.18)$ and 51 years and above (mean $=177.38$ ) are significantly higher than lecturers' teaching effectiveness with respect to overall teaching effectiveness for lecturers aged 31-40 years $($ mean $=162.26)$. Also, the significant Fisher's t-value of 5.03 indicates that lecturers' teaching effectiveness with respect to overall teaching effectiveness for lecturers aged 51 years and above (mean $=177.38$ ) is significantly higher than teaching effectiveness with respect to overall teaching effectiveness for lecturers aged $41-50$ years $($ mean $=167.18)$.

\section{DISCUSSION OF FINDINGS}

This study proposed age of lecturers as one of the attributes of teaching effectiveness. The findings of this study had revealed a significant influence of age of the lecturers on his/her teaching effectiveness-knowledge of subject matter, communication skill, effective teaching methods/strategies, classroom management skills, ability to motivate students, assessment of students learning activities, relationship with students, and overall teaching effectiveness. This finding has added to the scanty literature in the area.

This finding is not surprising as everything in life seems to improve with age, at least to a certain point in life. But that "certain point" in lecturers' teaching effectiveness is yet to be determined. This remains a challenge to researchers, but within the range of the lecturers' studied (20-56 years), age was found to have significant role to play in their teaching effectiveness. This finding seems to agree with Cohen, Macrae, and Jamieson (2008) who after 
10 evaluations per lecturer (surgeon) for a period of nine years gave an intra-class correlation of .65. Even with this moderately high correlation between age of the academics and their teaching effectiveness, the mean teaching effectiveness scores did not show any significant change over the nine years. The majority of the good and average surgeons maintained their teaching effectiveness scores (TES) ratings, and most of the poor grouping improved their TES.

The findings of this study seem to agree with many studies. The number of active neurons in the brain declines steadily during adulthood. Although the rate of loss is hard to measure, estimate of this loss range as high as 100,000 brain cells per day after age 30! As startling as these losses may seem, they apparently are "a drop in the bucket", as estimates of the number of neurons in our nervous system run as high as 180 billion. There is no clear evidence that the normal loss of brain cells has any functional significance (Larue \&Jarvik, 2002). It doesn't appear to contribute to senility, which is an abnormal deterioration in mental faculties seen in about $5 \%$ of people over 65 (Weiten, 2009).

Mental abilities and memory are relatively stable throughout most of adulthood. Decreases in the efficiency of long-term memory start to show up in some people after the age of 55 , but they tend to be small (Walsh, 2003). The memory lapses commonly associated with old age may often be due to a lack of interest rather than memory failure per se (Schaie\&Geiwitz, 2002). Still in the cognitive domain, age seems to take its toll on speed first. Many studies indicate that one's speed in learning, solving problems, retrieving memories, and processing information tends to decline with age (Birren, Woods, and Williams, 2010). This decline in mental speed may begin in middle adulthood, and it appears to be very gradual. Although mental speed may decrease, problem-solving ability remains fairly stable until later in life. Although there clearly are some decreases in mental efficiency after middle adulthood, many people remain capable of great intellectual accomplishment well into their later years. Agatha Christie was still grinding out mysteries in her 80s, and Andres Segovia continued to give concerts in his 90s (Weiten, 2009).

Several other studies, however, revealed conflicting results. On whether lecturers' teaching effectiveness decline with age, Sheeban, Dobson and smith (2008) reveal that age variables lose significance in all models except that for the physical and biological sciences. This loss in significance, they reason, is not surprising given the influence of age on teaching effectiveness at later ages was shown to be of very small size. They concluded that although effectiveness appears to improve with age, the teachers rated as most effective seem to retire early so that the remaining pool of professors will be of lower average effectiveness rating.

It is instructive to note that many of the variables that affect teacher quality (teaching effectiveness) are highly correlated with one another-for example, teacher's education levels, are typically correlated with age, experience, and general academic ability, and certification status is often correlated with content background as well as education, training and experience.

\section{CONCLUSION/RECOMMENDATIONS}

From the findings of this study, it was concluded that lecturers' age is a direct function of their teaching effectiveness. That is, the teaching effectiveness of lecturers, as evaluated by their students, is significantly influenced by the age of the lecturers in each of the eight subvariables of teaching effectiveness, viz: knowledge of subject matter, classroom communication skill, effective teaching methods/strategies, classroom, management skill, ability to motivate students, assessment of students learning activities, relationship with students, and overall teaching effectiveness.

The study recommends that lecturers should begin at individual classroom level to periodically evaluate their work and themselves using students, without waiting for formal government mandatory requirement since they and their students can benefit from such evaluations.

Workshops, seminars, conference should be organized by governments, lecturers, unions and other professional associations to enlighten the lecturers of all ages in particular and the public in general on the invaluable importance of students evaluation of instruction/instructor in the educational system. For instructional improvement, student evaluation of instruction serves as diagnostic tool.

\section{REFERENCES}

Bassey, B. A., 2006. Students' evaluation of teaching effectiveness of academic staff 
in University of Calabar, Nigeria. Unpublished Ph.D dissertation, Faculty of Education, University of Calabar.

Barren, J. E., Woods, A. M andWilliams, M. V., 2010.Behavioural slowing with age: Causes organization and consequences. In: $L$. W. Poon (Ed). Aging in the 1990s: Psychological issues. Washington Dc: American Psychological Association.

Cohen, R., Macrae, H and Jamieson, C., 2006. Teaching effectiveness of surgeons. The American Journal of Surgery, 171, (6): 612-614.

Kinney, D. P and Smith, S. P., 2002.Age and teaching performance.Journal of Higher Education. 63, (3): 282-302.

Larue, A andJarvik, L. F., 2002.Old age and biobehavioural changes. In: B.B. Wolman (ed). Handbook of developmental psychology. Englewood Cliff, New York: Prentice Hall.

Marsh, H. W and Dunkin, M. J., 2002. Student's evaluations of university teaching: $A$ multi-dimensional perspective. In: J. C. Smart (Ed), Higher Education: A handbook of theory and research. 8, (221-232). New York: Agathon.

Ndinechi, G. I., 2000. A guide for effective instruction in secondary school Business Education Journal, 11, (2): 13-22.

Radmacher, S. A and Martin, D. J., 2011. Identifying significant predictors of students' evaluations of faculty through hierarchical regression analysis: Journal of Psychology, 135, (3): 259-268.
Schaie, K. W andGeiwitz, J., 2002. Adult development and aging. Boston: Little, Brown.

Sheehan, B. A., Dobson, I. R and Smith, D. F., 2008.Academic staff implications of age discrimination legislation for Australian University.Ausinfo, 99, (2): 22-28.

Walsh, D. A., 2003. Age differences in learning and memory. In: D. S. Woodruff \& J. E. Brieen (eds). Research with the locus of control construct (Vol. 1) New York: Academic Press.

Watchtower Bible and Tract Society., 2009. How to live longer and feel better.Awake July, 22, 80, (2): 1-32.

Watchtower Bible and Tract Society (2009). Old age: Meeting the challenge. Awake, February, 87, (2): 1-32.

Weiten, W., 2009. Psychology: Themes and variations. California: Books and Cole Publishing Company. 